International Journal of Linguistics, Literature and Translation

ISSN: 2617-0299 (Online); ISSN: 2708-0099 (Print)

DOI: $10.32996 /$ ijllt

Journal Homepage: www.al-kindipublisher.com/index.php/ijltt

IJLLT

\title{
The Comparative Effects of Modern Dialogue Journal and Traditional Dialogue Journal on Critical Thinking: Iranian EFL Learners in Focus
}

\author{
Masoud Taheri ${ }^{1} \square$ and Reza Eidi² \\ ${ }^{1}$ Department of English, Shahreza Branch, Islamic Azad University, Shahreza, Iran \\ ${ }^{2}$ Academic Staff (Instructor), Farhangian University, Iran \\ $\square$ Corresponding Author: Masoud Taheri, E-mail: masoudtaheri1979@gmail.com
}

\section{ARTICLE INFORMATION ABSTRACT}

Received: 18 October 2021

Accepted: 14 November 2021

Published: 30 November 2021

DOI: $10.32996 / \mathrm{ijl} \mid \mathrm{t} .2021 .4 .11 .14$

\section{KEYWORDS}

Critical Thinking, Dialogue journal, EFL, Modern Dialogue Journal, Traditional Dialogue Journal
The current study explored whether critical thinking skills can be cultivated among Iranian EFL learners through keeping dialogue journals written through paper-and-pen (traditional) and through email (modern). Moreover, the study compared Traditional Dialogue Journal Writing with Modern Dialogue Journal Writing to see which one has probably a greater potentiality for improving critical thinking in an ELT context. To this end, it adopted a quantitative design and selected 85 participants non-randomly from among intermediate EFL learners in Iran. To collect the data, a Preliminary English Test as a homogeneity test and Watson-Glaser Critical Thinking Appraisal Form were utilized. Statistical analysis of the finding revealed that dialogue journaling, both traditional and modern, was a fruitful experience for developing critical thinking. Moreover, contrary to the researchers' assumption, traditional Dialogue journal proved to have a greater potentiality for the development of critical thinking. The study provides implications for ELT contexts.

\section{Introduction}

Like many, if not all, teachers across the world, the researcher of the present study who has been teaching EFL for a couple of years has taken much interest in fully and enthusiastically engaging in a quest for adopting and adapting innovative and effective approaches to teaching English at such learning contexts as English language institutes and universities across Isfahan located in Iran as the context of the present study. One of the techniques that she has recently gone after is dialogue journal writing conceptualized as a tool for developing writing skills in EFL learners. This technique is based chiefly upon writing in "a bound notebook in which students regularly carry on a private written conversation with the teacher for an extended period of time serving as functional, interactive, and deeply embedded in the continuing life of the classroom in which both student and teacher regularly write to each other in an informal, conversational style" (p.5). Now dialogue journals constitute an integral part of the repertoire of efficacious pedagogical methodologies and practices. In addition to writing skill enhancement, dialogue journal writing assumes the vital role of fostering the learners' critical thinking ability, defined by Facione (1990) as the purposeful, selfregulatory judgment which results in interpretation, analysis, evaluation, and inference, as well as explanation of the evidential, conceptual, methodological, or contextual considerations upon which that judgment is based.

The researcher's own teaching experience was supposed to serve as anecdotal evidence for attributing many benefits of using dialogue journals within the confines of the EFL classroom in terms of enhancing the learners' capability of approaching the written texts critically, skillfully, and actively. Interestingly enough, these anecdotally evident outcomes spurred her desire to gain empirical pieces of evidence for the reported high level of effectiveness associated with dialogue journal writing in boosting critical thinking skills (Khatib et al., 2012; Stout, 1993; Ghafar Samar et al., 2012, to name a few).

\section{Literature Review}

Khatib et al. (2012, p. 33) outline that "the most noticeable characteristics of the modern societies are growth and advancement in educational systems at speed". The outcome of this growth is changing the focus of educational systems from teachers to learners. In this forever-changing world, people who can use abundant data in generating new ideas are favored above those who lack the

Copyright: (c) 2021 the Author(s). This article is an open access article distributed under the terms and conditions of the Creative Commons Attribution (CC-BY) 4.0 license (https://creativecommons.org/licenses/by/4.0/). Published by Al-Kindi Centre for Research and Development, London, United Kingdom. 
ability to absorb information to create new ideas to solve problems. Therefore, the need for equipping learners with the rightthinking tools is urgent. It is imperative that people and especially students arrive equipped with the skills to question various points of view while maintaining respect for different opinions.

Zane (2013) holds that brain and educational research suggests that CT is an essential driver for learning and growth. Indeed, critical thinking is to knowing as listening is to hearing (Snyder \& Snyder, 2008). Truly and deeply learning the content of any discipline or profession can only occur via conscious and deliberate engagement with the content. Clearly then, critical thinking is not a new curricular or content area for us to teach. We are not teaching critical thinking per se. Instead, our goal is to help our students to think critically about the content.

It goes without saying that mental life enjoys some realizations of which critical thinking (CT) is a crucial component. CT is the ability to think clearly at the time of gathering or generating information. The National Council for Excellence in Critical Thinking (a non-profit organization based in the U.S.) defines critical thinking as the intellectually disciplined process of actively and skilfully conceptualizing, applying, analyzing, synthesizing, and/or evaluating information gathered from, or generated by, observation, experience, reflection, reasoning, or communication, as a guide to belief and action. Khatib et al., (2012) believe that thinking abilities can be assumed as the most noticeable and effective element in an educational system. "For acquiring this goal, paying attention to critical thinking is one of the fundamental phenomena and dimensions" (Hashemi et. al, 2010).

Given the broad spectrum of literature defining the concept of critical thinking, there is a correspondingly large number of perspectives on the concept's application. (Fung, 2014). Brown and Keeley (2007) accentuated the term critical thinking as an awareness of a set of interrelated questions, an ability to pose and answer critical questions at the appropriate time, and a desire to actively use the critical questions. They furthered their idea on critical thinking through this concept into two categories, namely weak-sense and strong-sense critical thinking. "Weak-sense critical thinking is the use of critical thinking to defend your current beliefs. Strong-sense critical thinking is the use of the same skills to evaluate all claims and beliefs, especially your own" (p. 10). Stout (1993) has noted that learners should be continually involved in the application of thinking skills if they are supposed to be accustomed to analyzing, conceptualizing, evaluating, and synthesizing what they have sought.

To boost critical-thinking skills during academic years is imperative for good and effective practice on the part of university students. Research evidence suggests that the present interactive instructional strategies in the Iranian educational system are far from being effective enough. Missing from the related literature are thick descriptions of how university teachers should organize the delivery of their curricula in such a way that critical thinking is developed. Hashemi et al, (2011) surveyed the critical thinking from the standpoint of many experts leading to leveling many criticisms at the Iranian educational system in that it has always been based on and oriented towards accumulating the learner's mind with a plentiful supply of data and information instead of creating thoughtful and mindful individuals who resemble computers with the task of storing information at the expense of constructing it. They have precisely pinpointed that "the main problem that the Iranian education system encounters is being goalcentered instead of being process-centered" (p. 68). In tandem with this claim, Alipour, Mehrabi, Saeid, and Safarpour (2009) carried out a longitudinal study evaluating the critical thinking abilities of 60 bachelor students at Payam-e Noor University in Shiraz, Southern Iran. The results revealed no significant difference between freshman and senior students. Accordingly, they concluded students' level of critical thinking did not increase during their education in Iran and they did not gain the necessary skills at the end of their education. Also, Eslami (2003), Khalili, et al, (2003), and Mirmowlaee (2003) reported similar claims attesting to the deficiencies of the system which should be lifted or reduced if the stakeholders intend to achieve the optimal quality of education.

Journal writing can be an effective method for improving learners' English ability; Casanave (1993) argues that '[i]n the Japan context, at least, journal writing may constitute the single most beneficial activity for the development of students' confidence and communicative ability in English'. Dialogue journal writing (DJW) is not based on strict methods of teaching but rather focuses on natural communication between student and teacher such as face-to-face conversations, over a set period of time. This allows the student to express their opinions without the stress and pressure of regular assessed written assignments. Martin, D'Arcy, Newton, and Parker (1976) argue that students feel apprehensive about taking risks because school writing is usually graded and criticized, possibly hindering students' development and their ability to write with confidence. DJW enables students to acquire the language by focusing on meaningful communication; 'the main reason cited for using journals is that they are seen as providing opportunities for authentic, meaningful communication which is focused on the message rather than the form; and that by doing so students will acquire the language' (Duppenthaler, 2004a, p. 2).

There are many advocates of dialogue journals (Baskin, 1994; Danielson, 1988; Dooley, 1987; El Koumy, 1998; Liao \& Wong, 2010). Baskin (1994) suggests that in order to be effective, teachers need to know and understand the capabilities, needs, and interests of their students as individuals. Teachers can then utilize that knowledge and tailor classes and teaching points accordingly. The 
use of dialogue journals enables teachers to acquire this knowledge due to the personal nature of journals. A significant benefit to students that resulted from the use of dialogue journals was the improvement in grammar acquisition (Duppenthaler, 2004a; Peyton, 1986). Reading and studying the teacher's entries and having to respond helped improve their grammar knowledge (Baskin, 1994).

\section{Objectives of the Study}

The purposes of the study were twofold: (1) to explore whether critical thinking skills can be cultivated among Iranian EFL learners through keeping dialogue journals written via paper-and-pen (traditional) and email (modern), on the one hand, and regular classroom techniques, on the other hand; and (2) to conduct a comparative study of two different instructional techniques including Traditional Dialogue Journal Writing (TDJW) and Modern Dialogue Journal Writing (MDJW) other hands.

\subsection{Research Questions}

In dealing with the mentioned issues stated above, the study purported to answer the following questions:

$\mathrm{RQ}_{1}$ : Does Traditional Dialogue Journal Writing have any significant effects on Iranian EFL learners' critical thinking skills?

$\mathrm{RQ}_{2}$ : Does Modern Dialogue Journal Writing have any significant effects on Iranian EFL learners' critical thinking skills?

$\mathrm{RQ}_{3}$ : Is there any significant difference between the effects of Modern Dialogue Journal Writing and Traditional Dialogue Journal Writing on Iranian EFL Learners' critical thinking skills?

\subsection{Research Hypotheses}

$\mathrm{HO}_{1}$ : Modern Dialogue Journal Writing does not have any significant effects on Iranian EFL learners' critical thinking skills.

$\mathrm{HO}_{2}$ : Modern Dialogue Journal Writing does not have any significant effects on Iranian EFL learners' critical thinking skills.

$\mathrm{HO}_{3}$ : There is not any significant difference between the effects of Modern Dialogue Journal Writing and Traditional Dialogue Journal Writing on Iranian EFL Learners' critical thinking skills.

\section{Methodology \\ 4.1 Research design}

The current study adopted a quantitative design. The study used a pretest-treatment-posttest method, using two homogeneous experimental groups. There were two independent variables called Modern Dialogue Journal Writing and Traditional Dialogue Journal Writing as well as a dependent variable named critical thinking.

\subsection{Participants}

Some 85 participants, selected non-randomly from among 127 participants, comprising intermediate EFL learners at a language institute, Iran, took part in the present study. Their age varied slightly (from 20-23) to the effect that the age range would be in line with Thomas and Litowitz's (2001) recommendation about the influence of maturation and experience on critical thinking. The participants were all registered in an academic course entitled Advanced Writing at the B.A. translation level. The textbook is named Paragraph Development was written by Martin L. Arnaudet and Mary Ellen Barrett (2004).

\subsection{Instruments}

To collect quantitative data for this study, two instruments were utilized: a Preliminary English Test (PET) as a homogeneity test, and Watson-Glaser Critical Thinking Appraisal Form (WGCTAF) which are presented in detail below.

\subsubsection{Preliminary English Test}

The first instrument utilized before the research intervention was the PET originally intended to select a homogenized research sample $(n=90)$ from the research population. PET is one of the standardized tests among the series written by Cambridge ESOL. It is an exam that requires the test takers to use everyday written and spoken English at an intermediate level. PET consisted of three sections, namely (1) reading and writing, (2) listening, and (3) speaking. Those test-takers whose scores fell between one standard deviation above and one standard deviation below the mean score were chosen to constitute the research participants discussed above. The time allocated for the first, second, and third sections of the test was 90,30 , and 15 minutes, respectively. The oral fluency and accuracy level before and after the intervention sessions were the major concern of the researcher.

The reading section included 35 multiple-choice items to each of which one point was assigned. The writing section comprised three components with 7 questions. The first part consisted of five production tests to each of which five marks were assigned. The second part asked the test takers to write a card to a friend. This writing task was of a 5-point value. The last section presented the testees two questions from which they were required to choose only one to answer. As for the listening component, it consisted 
of 25 multiple-choice items having 25 marks altogether. The speaking part of the PET had three sub-parts requiring the test takers to go in for an oral interview and perform a task by which some pictures were described. Some 15 marks were allocated to this question type. It goes without saying that such preliminary acts as calculating the item facility and item discrimination were indeed carried out, and the reliability level of the tests was also calculated using KR-21 to the effect that poor items were identified and eliminated from the whole test proved to be reliable.

After the PET was administered, the results helped sort the research population into three groups: low-proficiency (33\%), midproficiency (33\%), and high-proficiency (33\%) groups from which the intermediate group was selected to constitute the research sample. It goes without saying that the sorting was based on percentile ranking.

\subsubsection{Watson-Glaser Critical Thinking Appraisal Form}

The second instrument was the Watson-Glaser Critical Thinking Appraisal-Form (WGCTAF) developed by Watson and Glaser (1980). It includes five subsections of critical thinking abilities: the ability to define a problem; the ability to select pertinent information for the solution of a problem; the ability to recognize stated and unstated assumptions; the ability to formulate and select relevant and promising hypotheses; and the ability to draw conclusions validly and to judge the validity of inferences. The total number of items included in this questionnaire is equal to 80 . In addition to the face, content, construct, and criterion validity of the appraisal, its test-retest reliability was measured by Watson and Glaser (1980) as $r=0.89$. The scoring procedure was facilitated through the availability of an answer key, yielding a composite score for five subsections of the appraisal from 0 to 80 . The allocated time for filling up this questionnaire was about 50 minutes: inference, 13 minutes; recognition of assumptions, 6 minutes; deduction, 11 minutes; interpretation, 12 minutes; and evaluation of arguments, 8 minutes. Prior to the instructional period, WGCTAF deemed a pretest was distributed among the participants in order to check their current level of critical thinking abilities prior to any treatment sessions. It should be emphasized that WGCTAF was also utilized as a posttest after the treatment sessions.

According to West, Toplak, and Stanovich (2008), the Watson-Glaser Critical Thinking Assessment (WGCTA; Watson \& Glaser, 1980) is widely used and is representative of the discourse-logic-based critical thinking measures that have played a prominent role in critical thinking assessment. The WGCTA is an 80-item multiple-choice test that comprises five subsets of items (Inference, Recognition of Assumptions, Deduction, Interpretation, and Evaluation of Arguments). Each test item generally consists of a series of statements about which the validity of various conclusions must be judged. Four of the WGCTA's five subscales emphasize the propositional logic of necessity rather than sufficiency. The test's authors acknowledge that strong opinions and beliefs have the potential to adversely influence people's ability to think critically, and the WGCTA includes both neutral items and items on issues that are assumed likely to provoke a pressure to be biased. Thus, four of the five subscales admonish the test-taker to regard even factually questionable statements as correct for the purposes of the test (e.g., "For the purposes of this test, consider the statements in each exercise as true without exception"; "Try not to let your prejudices influence your judgment- just stick to the given statements [premises] and judge each conclusion as to whether it necessarily follows from the premises" [Harcourt Assessment, 2006, p. 4]). This emphasis on the importance of avoiding unbiased reasoning is also a common feature of the other discourselogic-based critical thinking measures (e.g., Cornell Critical Thinking Tests, Ennis, et al., 1985; California Critical Thinking Skills Test, Facione, 1992), and shares a common motivational underpinning with a number of tasks examined by cognitive scientists. Historically, Piaget's (1972) conceptualization of formal operational thought places such mechanisms of decontextualizationfreeing from irrelevant context-in positions of paramount importance, because in his view, "one of the essential characteristics of formal thought appears to us to be the independence of its form from reality content" (p. 10).

\subsection{Procedures}

Base on the results gained from the homogeneity test, the research sample was divided into three groups including two experimental groups and one control group. There were 30,28, 27 participants in the EG1, EG2, and CG, respectively. The EG1 and EG2 kept written dialogue journals, but the difference lied in the form of the dialogue journals. That is to say, EG1 members would write their journals in a notebook, but EG2 members were required to email their journal entries. To ensure the results of the study, the chosen classes were taught by the same teacher. Khatib (2012) asserts that the use of only one teacher for all classes helps the researcher to make sure that all research groups have received the same instruction, activities, tasks, and language practices. The EG1 and EG2 participants would write and email their journal entries, respectively, on a weekly basis during a semester (17 sessions) with no limitation in choosing topics. The two experimental groups were given the treatment for a period of 17 sessions, while the control group was given no special task but their regular classroom tasks.

Stout (1993) contends that providing a model for learners is one of the most effective ways in convincing students to get familiar with dialogue journals as a tool for processing ideas and engaging in a significant exploration of their ideas. After the teachers introduced dialogue journal writing and provided a model on the board, the first experimental group was asked to choose a topic of their interest and not to worry about grammar or spelling mistakes of their writing but instead to focus on expressing their thoughts and feelings freely on paper. They were allowed to use Farsi words in their sentences if they need a word for which they 
did not know the English equivalent. Students were informed that they could write journal entries on a wide range of topics: reflection on classroom activities, their teacher's behavior in the classroom, describing and explaining some characters in movies they had recently watched, stories about their life, problems they had faced while surfing the net and so on. The number of entries varied from student to student and from entry to entry -from less than half a page to several pages. The teacher would read and respond to the journal entries weekly. The focus of the responses was the content of the messages the students were trying to convey. The teacher commented on the points that students made, answered their questions, and asked questions that guided them to a more critical view. The teacher's comments were written down on the same paper submitted by the learners. Here are some examples, as Khatib (2012) mentioned, of the comments written by the teacher:

- Don't you think that police officers have the right to do so?

-You are too vague here, I didn't get the point.

-Wow! Really? Interesting! I didn't know that. Explain more about it!

-You are going too far. Focus on the main points and do not be confused.

-Have you ever thought about the significant role of speaking in English classes?

- Maybe this is the reason for what I have done in the classroom.

-Limit the topic!

-You should have considered different perspectives, not only just supporting your own belief.

-Would you do the same if you were in his shoes?

The other experimental group was acquainted with email dialogue journals through teachers' modeling and instructions. They were asked to prepare reflective email journals on a weekly basis during the semester. Topics of the email journals were also optional. Using an informal style, they would email ideas on their own topics. They would analyze the topic in the light of their personal experiences, opinions, and beliefs, focusing on the aspects of the topic that were most appealing to them. Each time the journals were turned in, the teacher would read them and respond by writing back his/her comments and observations, thereby creating a type of asynchronous dialogue with the students. As Liaw (2007) stated, the need for critical thinking in an L2 classroom does not mean that EFL learners lack the ability to engage in critical thinking. In fact, EFL students usually come to L2 classrooms with a variety of critical thinking skills developed in their L1. Many students are ready for and need to do critical thinking in L2. Since higher-order thinking skills are increasingly required for success in a knowledge-based society, it is the responsibility of EFL teachers to assist their students to acquire critical thinking skills while learning English. Without adequate practice in critical thinking, EFL students may lack a full "scaffold" to academic study, miss the opportunity to advance up the ladder in the global workplace, or not be able to actively participate in the international community.

The schedule for the participants coming from CG, on the other hand, was within the same number of class meetings, but they experienced NGJW meaning that they weren't exposed to any dialogue journal writing instruction. That is to say, the pretest was run in the first session, treatment was delivered in the next successive class sessions, and the posttest was given in the seventeenth session. Furthermore, each class was instructed in the same curriculum for the same amount of time, and with a similar number of students. Procedures set forth in the description of the instructional routines helped minimize threats to validity and further reduce the chances of contamination.

The participants had been supposed to submit their journals weekly, and the instructor would write/email response(s) to each entry, comment upon and grade them A through D for the presence of evidence of critical thinking abilities such as analysis, evaluation, and so on as well as their paying attention to different viewpoints. They were informed about the criteria of such grading. Papers scored low (D) if they showed little evidence of careful thought. Scores, also, encouraged the participants to consider more aspects of the topic under their discussion. After returning the journals, students were supposed to pay attention to the teacher's comments and questions again. Then, students would provide an answer to comments and questions offered by their teachers, and they would add some new points, too. They would keep and deliver journal entries as a profile to their teacher at the end of the semester. Regarding the CG, the teacher would have all the activities done in the other two classes except keeping journals. They had an ordinary class with no special tasks or treatment but their regular class tasks. Instead of keeping journals, they received a placebo. They were asked by the teacher to submit writing on the topic selected by the teacher. They were scored based on grammatical points, punctuation, content, and coherence. The three classes were scheduled and planned alike by the teacher. At a session prior to final exams, the participants took the Watson-Glaser Critical Thinking Appraisal once more in order for the researcher to learn whether the difference between groups was significant. The same procedure for ensuring the validity of the first administration was also repeated for the second one as well as the same method of scoring.

\subsection{Data Analysis}

The assumption of normality was examined through both the graphic of the histogram and also some numerical ways as recommended by Larson-Hall (2010). They indicated that all the data were normally distributed. 
The values of skewness and kurtosis statistics were within +/-1, based on Phakiti (2010); in addition, the outcomes of the ratio of skewness and kurtosis over their respective standard errors were within the ranges of $+/-1.96$, based on Field (2013). That's why the parametric t-test was used.

\section{Findings}

\subsection{Results for the first research question}

To find out whether there were any significant differences between the CG (i.e., no dialogue journal writing treatment), and EG1 (i.e., traditional dialogue journal writing treatment), the performance of the two groups on the Watson-Glaser Critical Thinking Appraisal Form was calculated as reported in the following table.

Table 1: CG and EG1 Groups Statistics on Critical Thinking

\begin{tabular}{llllll}
\hline & Group & N & Mean & Std. Deviation & Std. Error Mean \\
\hline \multirow{2}{*}{ CT } & CG & 27 & 24.0493 & 11.32320 & 1.04676 \\
& EG1 & 28 & 40.1207 & 9.249820 & .73607 \\
\hline
\end{tabular}

However, an independent t-test was performed to make sure the mean difference of the participants in the control and experimental group 1 is significant or not. The results of group statistics for this t-test are given in Table 2 .

Table 2: Independent sample t-Test on CG and EG1 Groups on Critical Thinking

\begin{tabular}{|c|c|c|c|c|c|c|c|c|c|}
\hline & & & \multicolumn{7}{|c|}{$\begin{array}{l}\text { Levene's Test for t-test for Equality of Means } \\
\text { Equality of } \\
\text { Variances }\end{array}$} \\
\hline & & $\mathrm{F}$ & \multirow[t]{3}{*}{ Sig. } & \multirow[t]{3}{*}{$\mathrm{T}$} & \multirow[t]{3}{*}{ df } & \multirow{3}{*}{$\begin{array}{l}\text { Sig. (2 } \\
\text { tailed) }\end{array}$} & \multirow{3}{*}{$\begin{array}{l}\text {-Mean } \\
\text { Difference }\end{array}$} & \multirow{2}{*}{\multicolumn{2}{|c|}{$\begin{array}{l}\text { Std. Error95\% Confidence } \\
\text { Difference Interval of the } \\
\text { Difference }\end{array}$}} \\
\hline & & & & & & & & & \\
\hline & & & & & & & & & Lower Upper \\
\hline \multirow{3}{*}{$\mathrm{CT}$} & Equal & variances.654 & .422 & .340 & 53 & .005 & -16.0714 & .21541 & $-.35699-.50342$ \\
\hline & assumec & & & & & & & & \\
\hline & $\begin{array}{l}\text { Equal } \\
\text { not assu }\end{array}$ & $\begin{array}{l}\text { variances } \\
\text { umed }\end{array}$ & & .343 & 51.24 & .005 & -16.0714 & .21339 & $-.35306 \quad-.49949$ \\
\hline
\end{tabular}

According to the results presented in table 2, the difference between the control group $(M=24.0493, S D=11.32)$ and the experimental group $1(M=40.12, S D=9.24)$, this difference is statistically significant $\left(P_{\text {value }}=0.005\right)$.

\subsection{Results for the Second research question}

To find out whether there were any significant differences between the CG (i.e. no dialogue journal writing treatment), and EG2 (i.e. modern dialogue journal writing treatment), the performance of the two groups on the Watson-Glaser Critical Thinking Appraisal Form was calculated as reported in the following table.

Table 3: CG and EG2 Groups Statistics on Critical Thinking

\begin{tabular}{llllll}
\hline & Group & $\mathrm{N}$ & Mean & Std. Deviation & Std. Error Mean \\
\hline \multirow{2}{*}{ CT } & CG & 27 & 24.0493 & 11.32320 & 1.04676 \\
& EG2 & 30 & 37.4909 & 8.14296 & .73607 \\
\hline
\end{tabular}

However, to make sure the mean difference of the participants in the control and experimental group 2 is significant or not an independent t-test was used. The results of group statistics for this t-test are given in the following table. 
Table 4: Independent sample t-Test on CG and EG2 Groups on Critical Thinking

\begin{tabular}{|c|c|c|c|c|c|c|c|c|c|}
\hline & $\begin{array}{l}\text { Leven } \\
\text { for } E \\
\text { Variar }\end{array}$ & $\begin{array}{l}\text { 's T } \\
\text { uality } \\
\text { ces }\end{array}$ & t-test & Equal & lity of $\mathrm{Me}$ & & & & \\
\hline & $\bar{F}$ & Sig. & $\bar{T}$ & $\mathrm{df}$ & $\begin{array}{l}\text { Sig. (2 } \\
\text { tailed) }\end{array}$ & $\begin{array}{l}\text {-Mean } \\
\text { Difference }\end{array}$ & $\begin{array}{l}\text { Std. } \\
\text { Difference }\end{array}$ & $\begin{array}{l}\text { Error95\% Confic } \\
\text { the Differe }\end{array}$ & cee Interval of \\
\hline & & & & & & & & Lower & Upper \\
\hline $\begin{array}{c}\text { Equal } \\
\mathrm{CT} \text { assumed }\end{array}$ & variances3.347 & .072 & -5.183 & 55 & .000 & -13.44156 & 2.59336 & -18.63876 & -8.24435 \\
\hline $\begin{array}{l}\text { Equal vari } \\
\text { assumed }\end{array}$ & iances not & & -5.182 & 53.22 & .000 & -13.44156 & 2.59336 & -18.63876 & -8.24435 \\
\hline
\end{tabular}

According to the results presented in table 4, the difference between the control group $(M=24.0493, S D=11.32)$ and the experimental group $2(M=37.49, S D=8.14)$, this difference is statistically significant $\left(P_{\text {value }}=0.000\right)$.

\subsection{Results for the third research question}

The third question of the study aimed at finding out whether there was any significant difference between the effects of Modern Dialogue Journal Writing and Traditional Dialogue Journal Writing on Iranian EFL Learners' critical thinking skills. To this end, the participant's scores on the critical thinking appraisal form in the two experimental groups were tabulated as follows.

Table 5: EG1 and EG2 Groups Statistics on Critical Thinking

\begin{tabular}{llllll}
\hline & Group & $\mathrm{N}$ & Mean & Std. Deviation & Std. Error Mean \\
\hline \multirow{2}{*}{ CT } & EG2 & 30 & 37.4909 & 8.14296 & .73607 \\
& EG1 & 28 & 40.1207 & 9.249820 & .73607
\end{tabular}

As displayed in the table above, observationally, EG2 outperformed EG1 in the critical thinking appraisal form. Therefore, to make sure the difference between the two groups is statistically significant another independent sample t-test was run.

Table 6: Independent sample t-Test on EGI and EG2 Groups on Critical Thinking

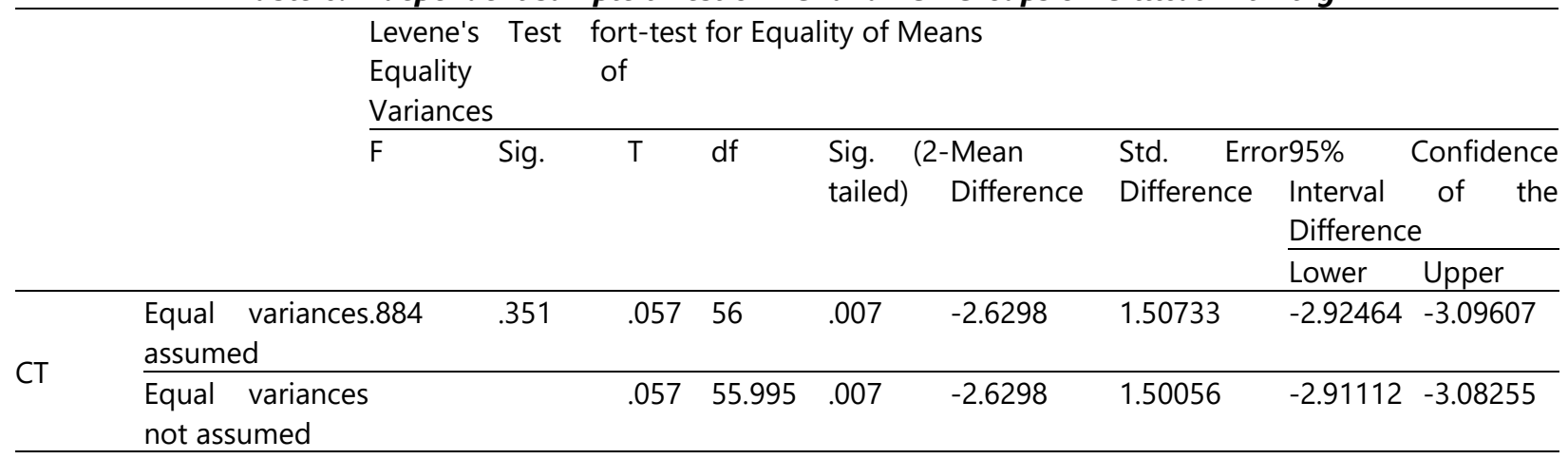

Table 6 shows that TDJW group $(M=40.12, S D=9.24)$ outperformed MDJW group $(M=37.49, S D=8.14)$ significantly $\left(P_{\text {value }}=0.007\right)$. Consequently, it can safely be concluded that the paper-and-pen approach to dialogue journaling turned out to be more influential in enhancing the students' critical thinking skills than its modern counterpart.

\section{Discussion}

The current study was an attempt to shed light on the potential that dialogue journal writing can have for honing university students' critical thinking skills. Throughout the study, journaling was practiced differently by the experimental groups. That is to say, one of the experimental groups received instruction on how to develop the critical thinking skill through a traditional approach to journaling that was oriented towards the use of a pen to write the journal on a piece of paper as part of a bound notebook intended chiefly for dialogue journaling. The other experimental group was exposed to dialogue journaling through electronic or email messages exchanged between the students and the teacher. Needless to say, this approach was modern in comparison with the one adopted by the other group. The control group of the study, on the other hand, was delivered the same amount of instruction as the two experimental groups on other writing techniques discussed in the procedure section of the third chapter. 
As for the first and second research questions, the results revealed that dialogue journaling was a fruitful experience by which those study participants involved in the experimental groups of the study developed their level of critical thinking skill after they were exposed to journaling practice realized in the form of a bound notebook and email messages in the EG1 and EG2, respectively. This finding is in line with the one gained by Khatib et al. (2012) who compared two audiotaped and written dialogue journals used in EFL classrooms in order to investigate their impact on the enhancement of critical thinking. Analyses exhibited a significant difference between the experimental groups and the comparison group giving evidence that overtly teaching for critical thinking abilities through keeping dialogue journals.

Moreover, some other scholars believe that dialogue journals can be considered as a forum for critical reflection. For instance, Stout (1993) and Walker (2006) are in favor of dialogue journals that are deemed effective tools for accounting for critical considerations in the realm of student learning. Lee (2004) applied dialogue journaling to the teacher education context. He made the claim that dialogue journaling, once applied in the pre-service teacher preparation context, can serve many functions and achieve a multitude of purposes one of which is the enhancement of the teachers' critical thinking skills. Sharing the same thought, McDonald (1997) opined that ESL journal writing brings about effective reflections and therefore adjustments to life.

In response to the third research question, it was concluded that the traditional version of dialogue journal writing outperformed the modern version. As evidenced from the results, the paper-and-pen dialogues were shown to be factors contributing to the nurturing of the participants' critical thinking skills. Placing this finding alongside those of previous studies in the related literature, it can safely be claimed that this study corroborates the findings gained by Mirhosseini and Ghajar (2005), Ghafarsamar, and Ahmadi (2012), Gokhale (1995), Reinertsen and Wells (1993).

Unlike these traditional types of journaling, the modern dialogue journals seem to have gone unnoticed and unexplored in the related literature. Such a dearth of research into the effect of electronic journaling on boosting critical thinking skills seems to be owing to the burgeoning interests of scholars in online learning. Umar and Rathakrishnan's (2012) study aimed to investigate the effects of online teachers' social roles and students' learning styles on their performance and critical thinking skill in a wiki environment. A total of 120 high school students from two sub-urban secondary schools in a northern state in Malaysia were involved in this $2 \times 2$ factorial quasi-experimental study. The students were instructed to write and edit their essays in the wiki with the assistance of e-moderators with either social roles (SROT) or pedagogical roles (PROT). While a learning style questionnaire was used to measure the students' active or reflective learning style, their post-test scores were used to gauge their essay performance. Also, their postings in the wiki environment were analyzed to determine their critical thinking. The findings indicated that the SROT group performed significantly lower in essay performance than the PROT group. However, there were no significant differences in critical thinking and performance between the reflective and active students in the SROT group. This study revealed that as the roles of SROT teachers are limited, it has affected the students' performance. Also, the differences in learning style did not influence their performance and critical thinking in a wiki environment.

\section{Conclusion and implications}

From the finding, it can safely be concluded that the present research enterprise can be conceived of as a platform for taking into consideration a window that dialogue journaling as a learning technique can open to nurturing the students' critical thinking skills. To date, dialogue journaling has been investigated from different perspectives with the result that it seems to be of multiple but various types such as paper-and-pen (e.g. Holmes and Moulton, 1997; Peyton, 2000; Bolton, 2013; Orem, 2001; Kose, 2005), oral (e.g. Henry, 1994; Nama and Ramazanazdeh, 2011; Marefat and Mouladoust, 2011), audiotaped (e.g. Siyli and Kafes, 012; Harley, 1993; Rashtchi et al. 2011), videotaped (e.g. Richards and Renandya, 2002), and electronic (Othman et al., 2007; Colleen, 2010; Shang, 2007; Staton et al., 2005; Longhurst, 2004; Britsch, 2001). Of all these types, electronic dialogue journals appear to have gone underexplored when it comes to critical thinking cultivation.

The present study has some pedagogical implications. The English Language Teaching (ELT) can be an appropriate context for learning and teaching in which the findings of the current study, albeit not readily generalizable, can be applied in order for the student's critical thinking ability to be cultivated. In addition, Iran could be a particular site for the utilization of all the findings.

Funding: This research received no external funding.

Conflicts of Interest: The authors declare no conflict of interest. 


\section{References}

[1] Alipour, A., Mehrabi, M., Saeid, N., \& Safarpour, A. R. (2009). Evaluation of Critical Thinking of the Students in Shiraz, Southern Iran. IRCMJIranian Red Crescent Medical Journal, 11 (4): 466-467.

[2] Baskin, R. S. (1994). Student Feedback on Dialogue Journals.

[3] Browne, M. N., \& Keeley, S. M. (2007). Asking the right questions: A guide to critical thinking. Pearson Education.

[4] Casanave, C. P. (1993). Student voices: The insiders speak out on journal writing. AUTHOR Casanave, Christine Pearson, Ed. TITLE Journal Writing: Pedagogical Perspectives. [SFC Monograph, 98.

[5] Danielson, K. E. (1988). Dialogue Journals: Writing as Conversation. Fastback 266.

[6] Dooley, M. S. (1987). Dialogue Journals: Facilitating the Reading-Writing Connection with Native American Students.

[7] Denne-Bolton, S. (2013). The Dialogue Journal: A Tool for Building Better Writers. In English Teaching Forum (Vol. 51, No. 2, 2-11). US Department of State. Bureau of Educational and Cultural Affairs, Office of English Language Programs, SA-5, 2200 C Street NW 4th Floor, Washington, DC 20037.

[8] Duppenthaler, P. (2004). A study of the effect of three different types of feedback on writing: Part 3- Discussion and conclusions. Studies and Essays (Journal of the Faculty of Literature, Tezukayama Gakuin University), 40, 1-19.

[9] Eslami-Akbar, R. (2003). A comparative study of critical thinking skills of first and last semester students of Nursing working in selected hospitals of Iran, Tehran, and Shahid Beheshti medical health service universities [Ms. Thesis]. Tehran: Iran Medical and Health Services University.

[10] El-Koumy, A. S. (1998). Effect of Dialogue Journal Writing on EFLStudents' Speaking Skill. Education Resources Information Center (ERIC), USA.

[11] Facione, P. (1990). Critical thinking: A statement of expert consensus for purposes of educational assessment and instruction (The Delphi Report).

[12] Field, A. (2013). Discovering statistics using IBM SPSS statistics. Sage.

[13] Fung, D. (2014). Promoting critical thinking through effective group work: A teaching intervention for Hong Kong primary school students. International Journal of Educational Research, 66, 45-62.

[14] Ghahremani-Ghajar, S. S., \& Mirhosseini, S. A. (2005). English class or speaking about everything class? Dialogue journal writing as a critical EFL literacy practice in an Iranian high school. Language, culture and curriculum, 18(3), 286-299.

[15] Gokhale, A. A. (1995). Collaborative Learning Enhances Critical Thinking. Journal of Technology Education, 7, 22-30.

[16] Hashemi, S. A., Naderi, E., Shariatmadari, A., Naraghi, M. S., \& Mehrabi, M. (2010). Science production in the Iranian educational system by the use of critical thinking. International Journal of Instruction, 3(1).

[17] Henry, L. M. (1994). Oral Dialog Journals: A Learner-Centered Approach.

[18] Holmes, V. L., \& Moulton, M. R. (1997). Dialogue journals as an ESL learning strategy. Journal of Adolescent \& Adult Literacy, 40(8), 616-621.

[19] Khatib, M., \& Mehrgan, K. (2012). Achieving critical thinking skills through reading short stories. Advances in digital multimedia, 1(3), 155172.

[20] Stout, C. J. (1993). The dialogue journal: A forum for critical consideration. Studies in Art Education, 35(1), 34-44.

[21] Samar, R. G., \& Basiroo, S. R. CRITICAL THINKING ASSESSMENT: SPECIFYING THE. www. mjltm. com submit@ mjltm. com hamedghaemi@ email. com, 51.

[22] Snyder, L. G., \& Snyder, M. J. (2008). Teaching critical thinking and problem-solving skills. The Journal of Research in Business Education, 50(2), 90.

[23] Stout, C. J. (1993). The dialogue journal: A forum for critical consideration. Studies in Art Education, 35(1), 34-44.

[24] Khalili, H., Baba Mohammadi, H., Hadji Aghadjani, S., \& Qods, A. A. (2003). The effects of two educational methods, classic and critical thinking strategies (CTS), on the stable learning of nursing students. Journal of Medical Education, 3(2).

[25] Mirmowlaee, S. T. (2003). Comparison between the critical thinking of freshmen and senior students of midwifery of Tehran Universities of Medical Sciences. Hayat Quarterly J, 22, 69-77.

[26] Martin, N., D'Arcy, P., Newton, B., \& Parker, R. (1976). Writing and learning across the curriculum, 11-16. Montclair, NJ: Boynton.

[27] Köse, E. (2005). Impact of dialogue journals on language anxiety and classroom effect (Doctoral dissertation, Bilkent University).

[28] Liaw, M. L. (2007). Content-based reading and writing for critical thinking skills in an EFL context. English Teaching and Learning, 31(2), 4587.

[29] Liao, M. T., \& Wong, C. T. (2010). Effects of dialogue journals on L2 students' writing fluency, reflections, anxiety, and motivation. Reflections on English Language Teaching, 9(2), 139-170.

[30] Lee, I. (2004). Using dialogue journals as a multi-purpose tool for preservice teacher preparation: How effective is it? Teacher Education Quarterly, 31(3), 73-97.

[31] Longhurst, J., \& Sandage, S. A. (2004). Appropriate technology and journal writing: Structured dialogues that enhance learning. College Teaching, 69-75.

[32] Orem, R. A. (2001). Journal writing in adult ESL: Improving practice through reflective writing. New Directions for Adult and Continuing Education, 2001(90), 69-78.

[33] Peyton, J. K. (1986). Dialogue Journal Writing and the Acquisition of English Grammatical Morphology.

[34] Peyton, J. K. (2000). Dialogue Journals: Interactive Writing To Develop Language and Literacy. Revised. ERIC Q\&A.

[35] Piaget, J. (1972). Intellectual evolution from adolescence to adulthood. Human Development, 15(1), 1-12.

[36] Phakiti, A. (2010). Analyzing quantitative data. Continuum companion to research methods in applied linguistics, 39-49.

[37] Reinertsen, P. S., \& Wells, M. C. (1993). Dialogue journals and critical thinking. Teaching Sociology, 21(2), 182-186.

[38] Umar, I. N., \& Rathakrishnan, M. (2012). The effects of online teachers' social role and learning style on students' essay writing performance and critical thinking in a wiki environment. Procedia-Social and Behavioral Sciences, 46, 5730-5735.

[39] Siyli, N. A., \& Kafes, H. (2012). Audio journal in an ELT context. International Journal of Applied Linguistics and English Literature, 1(4), 66-75. 
[40] Rashtchi, M., \& Sadraeimanesh, F. (2011). Is debate a useful strategy in enhancing the reading comprehension and critical thinking of Iranian EFL learners? Theory and Practice in Language Studies, 1(4), 361-369.

[41] Richards, J. C., Richards, J. C., \& Renandya, W. A. (Eds.). (2002). Methodology in language teaching: An anthology of current practice. Cambridge university press.

[42] Shang, H. F. (2007). An exploratory study of e-mail application on FL writing performance. Computer Assisted Language Learning, 20(1), 7996.

[43] Walker, S. E. (2006). Journal Writing as a teaching technique to promote reflection. Journal of Athletic Training, $41(2), 216$.

[44] West, R. F., Toplak, M. E., \& Stanovich, K. E. (2008). Heuristics and biases as measures of critical thinking: Associations with cognitive ability and thinking dispositions. Journal of educational psychology, 100(4), 930. 